\title{
THE IMPLICATIONS OF EXPANDING THE AUTHORITY OF THE PRETRIAL POST-VERDICT JUDICIAL REVIEW OF THE CONSTITUTIONAL COURT IN DECIDING WHETHER IT IS A VALID DETERMINATION OF THE SUSPECT AGAINST LAW ENFORCEMENT AND THE PROTECTION OF THE RIGHTS OF THE SUSPECT
}

\author{
Seno Wibowo Gumbira, Ratna Nurhayati, Purwaningdyah Murti Wahyuni \\ Faculty of Law Social Science and Political Science, \\ Universitas Terbuka, Jakarta \\ E-mail: seno@ecampus.ut.ac.id; anna@ecampus.ut.ac.id;
}

\begin{abstract}
The purpose of this study is to determine whether there are implications of expanding the authority of the pretrial post-verdict judicial review of Constitutional Court in deciding whether it is a valid determination of the suspect against law enforcement and the protection of the rights of the suspect. This research belongs to normative research. The results of the study show that there is a false application of "Legal Reasoning by Analogy" (argumentum per analogiam) in pretrial decision Number: 04/Pid.Prap/2015/PN.Jak.Sel, while while the use of historical interpretation method (historiche intepretatie) in the judicial review judgment of the Constitutional Court of the Republic of Indonesia Number: 21 / PUU-XII / 2014 indicates that the Constitutional Court has exceeded its original function where negative legislator became positive legislators form or add a new norm. These applications are deemed to be against the principle of quick, simple, and low budget and the principle of litis finiri oportet in the criminal justice system and inhibits the process of law enforcement settlement." For a more-efficient sentence.
\end{abstract}

Keywords: Pretrial post-verdict judicial review, Valid determination.

\section{A. INTRODUCTION}

The Republic of Indonesia is a Rule of Law country, as confirmed on Article 1 Paragraph 3 in the Provisions of 1945 Constitution. The concept of a rule of law intended to avoid any state's or government's action that is done arbitrarily, thus all State's actions in legislative, executive and judiciary levels must be based on the law that set it up. It is in accordance with thus all State's actions in legislative, executive and judiciary levels must be based on the law that set it up Rule of law concepts expressed by Soemantri Martosoewignjo, namely that the government in carrying out the duties and obligations must be based on law or

Yustisia Vol. 7 No. 1 January - April 2018

The Implications Of Expanding... 
regulations, the assurance of human rights (citizens), the division of power in the state, the supervision of judicial bodies (Soemantri, 1990: 29).

The concept of rule of law proposed by Soemantri Martosoewignjo above, especially on the "supervision of the judicial bodies" that showed the presence of one form of the concept of checks and balances between all actions on State or the State Apparatus of its citizens according to the law and uphold human rights. This can be clearly seen clearly seen by the existence of the Constitutional Court of Indonesia and other judicial institutions under the auspices of the Supreme Court of Indonesia, such as the State Administrative Court, which acts as supervisor to consider whether a particular action taken by the State Apparatus is unlawful or harms its citizens? And there are also in the criminal justice system namely Pretrial as overseer of the horizontal action against investigators.

As it is known that the Pretrial is one of the institutions in Indonesian criminal law, which is formally regulated in the Criminal Procedure Code, whose practice is used by parties / institutions that filed efforts to dissatisfy the application of law or action / decision of the legal apparatus which is considered to have injured the sense of justice and the interests of Suspects / Seekers of Justice. The pretrial authority in the Indonesian Criminal Procedure Code is contained in the provisions of Chapter X entitled "The Power of Courts to Judge" in Articles 77 and 95. In particular, the title of the Chapter in the first section is "Pretrial ", especially in the provisions of Article 77 of the Criminal Procedure Code, there is correlation with the definition of Pretrial on the provisions of Article 1 point 10 of the Criminal Procedure Code. The pretrial authority provided for in Article 77 of the Criminal Procedure Code, namely:

"The District Court is authorized to examine and decide upon, in accordance with the provisions of this Law concerning:

a) Whether it is a valid arrest, detention, termination of investigation, or termination of prosecution;

b) Compensation and or rehabilitation for a case of the punishment is stopped at the level of investigation or prosecution".

Meanwhile, the pretrial authority contained in the Criminal Procedure Code in Article 95 regarding compensation and rehabilitation, which reads entirely:

1) The suspect, the defendant or the convicted has the right to demand compensation because of arrested, detained, charged, and prosecuted or subjected to any other action, without reasons based on the law or because of misrepresentations about the man, or the law that is applied; 
2) A compensation claim by the Suspect or his heirs upon the arrest or detention as well as other actions without reasons based on the law or because of misrepresentations about the person or law that applied as referred to in paragraph 1 that the case is not submitted to the District Court, decided in the trial court as referred to in Article 77".

However, the authorities of the Pretrial, as outlined above, has experienced an expansion that includes a prosecute whether it is valid or not a stipulation of suspects against the subjects of law. This began with the Constitutional Court granting part of Judicial Review of Law Number 8 Of 1981 regarding Criminal Procedure Code filed by the convict of corruption case of fictitious bioremediation of PT. Chevron Pasific Indonesia Bachtiar Abdul Fatah. The Constitutional Court granted Judicial Review was because the Judicial Review was "the Criminal Procedure Code does not have a system check and balance for the act of determining the suspect by the investigator because of the absence of a testing mechanism on the validity of the acquisition of evidence. "The Indonesian Criminal Procedure Code has not applied the full due process of law principle because the actions of law enforcement officers in searching and finding the evidence cannot be tested the validity of its acquisition" (Hanifa, http://www.mahkamahkonstitusi.go.id/index.php?page=web.Berita\&id=10796\#. WIXAeqiWbs0 downloaded on January 10, 2018).

Furthermore, the Decision of Judicial Review of the Constitutional Court of the Republic of Indonesia Number 21/PUU-XII/2014 is in line with No:04/Pid.Prap/2015/PN.Jak.Sel with the request of Pretrial Investigation on the validity of the suspect in the alleged corruption in the alleged corruption case with the Applicant namely Commissioner General Budi Gunawan through the South Jakarta Pretrial in which the examination and verdict on the case were conducted by Judge Sarpin. In the verdict, the Court granted the petition of the petitioner that the determination of a suspect conducted by the Corruption Eradication Commission was declared invalid. The verdict raises the pros and cons of both academics and legal practitioners in Indonesia. However, in the legal considerations of the Pretrial Decision No:04/Pid.Prap/2015/PN.Jak.Sel did not mention the Decision of Judicial Review of the Constitutional Court Number 21/PUU-XII/2014 as the legal basis for granting the petition.

As it is known that the decision of the Constitutional Court cannot be separated from erga omnes principle which has legally binding force on all components of the nation, so all parties must submit and obey the decision (Asy'ari, Hilipito and Ali, 2012). In the case of Judicial Review in the Constitutional Court, the legal norm that is abstract and publicly binding is being tested. Although the basis of the petition for judicial review is that 
the applicant's constitutional rights were harmed, but the action truly represents the interests of the law throughout the community, namely the establishment of the constitution (Safa'at: 2).

The birth of the Constitutional Court's judicial review decision, the Pretrial Appeal on the suspect's determination has legal basis to be brought to court, however, there are special characteristics of the filing of the pretrial related to the determination of the suspect namely 1). The determination of the suspect is invalid because are the investigation of witnesses, experts, suspects, searches, and seizures is made after the suspect's determination so as not to fulfill 2 (two) evidence, 2). The second pretrial application concerning the determination of the suspect cannot be categorized as ne bis in idem because it is not their subject matter, 3). The determination of suspects on the basis of developmental results Investigations of other suspects in different files are invalid. The Constitutional Court decision surely has a very significant impact in the process of law enforcement, especially in the field of criminal law, especially the protection of the human rights of the suspect.

In order to anticipate the implementation of filing application for Pretrial Investigation based on based on the decision of the Judicial Review of the Constitutional Court, the Supreme Court create the Supreme Court Regulation Number 4 Of 2016 On the Prohibition of Reconsideration Pretrial Decision (Supreme Court Regulation Number 4 Of 2016) in which it is set and mentioned that filing the reconsideration on the decision of the case pretrial is now prohibited. The Supreme Court Regulation of the prohibition the Reconsideration Pretrial case makes every pretrial case cannot filed the Cassation, reconsideration incuding an appeal.

\section{B. PROBLEM STATEMENT}

With the decision of the judicial review of Constitutional Court and Supreme Court Regulation Number 4 Of 2016, the writers want to discuss what are the implications of the expansion of the authority of the Pretrial post-verdict judicial review of Constitutional Court in deciding whether it is a valid determination of the suspect to law enforcement and the protection of the rights of the suspect?

\section{RESEARCH METHOD}

This study is using the normative method, which is explorative-analytical. The data used are secondary data, in the form of primary legal materials and secondary legal materials (Soekanto and Mamuji, 2007: 13-14). Holding a scientific research should clearly use the method. Method means searching for 
information in a planned and systematic way. The steps taken must be clear and there are strict limitations to avoid overly broad interpretation. To examine the existing problems, this research uses a doctrinal juridical approach, namely the approach that sees the law as a doctrine or set of rules that are normative. This approach is done through the study or legal literature research. In this case the author analyzes the comparison of law, legal principles, norms of positive law, and the opinion of scholars or jurists.

The data used in this study is secondary data in the form of documents, books, scientific papers and papers, journal magazines and others. After the secondary data are collected then analyzed qualitatively to analyze and answer the problem.

\section{DISCUSSION AND RESEARCH RESULT}

\section{D.1. The Implications Of Expanding The Authority Of The Pretrial Post- Verdict Judicial Review Of The Constitutional Court In Deciding Whether It Is A Valid Determination Of The Suspect Against Law Enforcement And The Protection Of The Rights Of The Suspect}

Before discussing what are the implications of extending the authority of the Pretrial after the judicial review of the Constitutional Court of the Republic of Indonesia in deciding whether it is a valid determination of the suspect against law enforcement and the protection of the suspect? The author will first discuss the method of interpretation used by the judges of Pretrial to grant the unlawful application of the determination of the suspect in Decision No: 04/Pid.Prap/2015/PN.Jak.Sel or by the Constitutional Court Justices through judicial review on decision Number 21/PUU-XII/2014. So that will be discussed in a systematic way.

Basically before the Decision No No: 04/Pid.Prap/2015/PN.Jak.Sel as well as by the judges of the Constitutional Court through judicial review on the decision Number 21/PUU-XII/2014 Pretrial authority set out in the Criminal Procedure Code in Article 77 has been regulated explicitly and limitedly namely:

1. Whether it is a valid arrest, detention, termination of investigation, or termination of prosecution;

2. Compensation and or rehabilitation for a case of the punishment is stopped at the level of investigation or prosecution

3. Rehabilitation and indemnification by the Suspect or his heirs of arrest or detention and other acts without cause based on law or by mistake regarding the person or law applied. 
However, after the Decision No: 04 / Pid.Prap / 2015 / PN.Jak.Sel or by the Panel of Judges of the Constitutional Court through judicial review on Decision Number 21 / PUU-XII / 2014, the Pretrial Authority of its object is increased by examining and deciding whether it is a valid determination of a suspect by the investigator. Thus, the addition of a new norm that did not exist previously. The question is whether the judiciary can make a new norm through the judges/court council?

As known based on Law Number 48 Of 2009 on Judicial Power, in essence there are provisions that mention (two) 2 things that include very principal namely:

1. The court is prohibited to refuse to examine, hear and decide a case filed with the pretext that the law does not exist or is less evident, but requires to examine and adjudicate it is a concrete of the principle of Ius Curia Novit as governed by the provisions of the Judicial Power Law Article 10;

2. A judge and the Constitutional Judge is obliged to dig, follow and understand the legal values and sense of justice that is alive in the community. Contained in Article 5 of the Law of the Judicial Power.

In addition, in the science of law there is the doctrine sens clair (la doctrine $d u$ sens clair). In the adherents of this school argue that "judicial discovery of the law" is only necessary if:

a. The rules do not yet exist for a case in concreto; or

b. The rules already exist, but they are not yet clear in this view (Ali, 2015: 164).

Meanwhile, according to Michel Van Karckhove as quoted by Achmad Ali has concluded the doctrin sens clair in the following five points:

a. There is a text of the law understood by its own meaning and based on any previous explanation and is unlikely to cause any doubt;

b. Because the language of the law is based on the everyday conversation, then it can be considered all terminology that is not determined by lawmakers are the same meaning with which belonged to in the everyday conversation;

c. The blurring of a text of the law is only possible because it contains two meanings or due to lack of constant common sense of those terms.

d. Idealy, what should be used as a guidance by legislators is formulaty legal text in clearty as possible in order to prevent inconsistency in its formulation. 
e. To know the presence of vagueness or the absence of vagueness of text is not necessary interpretation. On the contrary, the recognition of details or blurring of the text generate criteria that allow judging whether one interpretation or the discovery of law or is not required. If it is required or not required, the result in the application of the law is legitimate (Ali, 2015: 165).

When viewed from the doctrine of sen clair (la doctrine du sensclair) at a glance indeed the judge may have made a legal discovery of a case where there is no legal instrument or law is blurred or ambiguity. Further questions, what are the parameters of judges in making legal discovery when faced with cases that have no clear rules and what legal discovery methods are allowed ?. Therefore, to answer the question, it is necessary to look at the considerations in the decision of the Pretrial No: 04/Pid.Prap/2015/PN.Jak.Sel and Consideration of the Decision of the judicial review of the Constitutional Court Number 21/PUU-XII/2014, namely as follows:

\begin{tabular}{|c|c|}
\hline $\begin{array}{l}\text { Consideration Of The Pretrial Decision } \\
\text { No: 04/Pid.Prap/2015/PN.Jak.Sel }\end{array}$ & $\begin{array}{l}\text { Consideration of the Decision of the } \\
\text { judicial review of the Constitutional } \\
\text { Court Number 21/PUU-XII/2014 }\end{array}$ \\
\hline $\begin{array}{l}\text { 1) "Considering from the formulation of } \\
\text { the definition of Article } 1 \text { paragraph } 10 \\
\text { Article Jo } 77 \text { Jo in article } 82 \text { paragraph } \\
\text { (1) and (2) of the criminal procedure } \\
\text { code is clearly known, that whether it } \\
\text { is a valid determination of the Suspect } \\
\text { does not enter the object Pretrial, } \\
\text { because it was not regulated" }\end{array}$ & $\begin{array}{l}\text { 1) In accordance with the mandate of } \\
\text { Article } 1 \text { Paragraph (3) of the } 1945 \\
\text { Constitution of the Republic of } \\
\text { Indonesia which stipulates that } \\
\text { Indonesia is a legal state, where the } \\
\text { principle of due process of law as } \\
\text { one of the manifestations of human } \\
\text { rights recognition in the criminal } \\
\text { justice process becomes a principle } \\
\text { that must be upheld by all parties, } \\
\text { law enforcement agencies }\end{array}$ \\
\hline $\begin{array}{l}\text { 2) Considering that the authority of the } \\
\text { judge to establish the original law does } \\
\text { not exist, is made by using the method } \\
\text { of legal discovery (rechtsvinding), } \\
\text { which if examined scientifically } \\
\text { (scientific) and juridically must be } \\
\text { accountable }\end{array}$ & $\begin{array}{l}\text { The system adopted in the } \\
\text { Criminal Procedure Law is the } \\
\text { " accusatory ", ie the suspect } \\
\text { or defendant is positioned as a } \\
\text { human subject having the } \\
\text { same dignity and status before } \\
\text { the law. In order to protect the } \\
\text { rights of suspects or } \\
\text { defendants, the Criminal } \\
\text { Procedure Law provides a } \\
\text { mechanism for control over } \\
\text { possible arbitrary actions of }\end{array}$ \\
\hline
\end{tabular}




\begin{tabular}{|c|c|}
\hline & $\begin{array}{l}\text { investigators or } \\
\text { prosecutors through } \\
\text { institutions }\end{array}$ \\
\hline $\begin{array}{l}\text { 3) Considering that the authority of the } \\
\text { judge to set a law that was } \\
\text { originally not clear becomes clear is } \\
\text { performed using and set the } \\
\text { interpretation method }\end{array}$ & $\begin{array}{l}\text { 3) The Criminal Procedure Law does } \\
\text { not have a check and balance } \\
\text { system for the act of determining } \\
\text { Suspects by investigators, because } \\
\text { the Criminal Procedure Law does } \\
\text { not recognize the mechanism of } \\
\text { testing of the validity of the } \\
\text { acquisition of evidence and does } \\
\text { not apply the exclusionary } \\
\text { principle of unlawfully obtained } \\
\text { evidence }\end{array}$ \\
\hline $\begin{array}{l}\text { 4) Considering .... it must be understood } \\
\text { the sense and meaning 'act of force' } \\
\text { correctly, that all actions of the } \\
\text { Investigator in the process of the } \\
\text { Investigation and any acts of the } \\
\text { Prosecutor in the prosecution process } \\
\text { is a forced effort for having placed or } \\
\text { use the label Pro Justice in every } \\
\text { action }\end{array}$ & $\begin{array}{l}\text { 4) The nature of the existence of } \\
\text { pretrial institutions is as a form of } \\
\text { supervision and mechanism of } \\
\text { objection to the law enforcement } \\
\text { process that is closely related to the } \\
\text { guarantee of human rights } \\
\text { protection, but in the course of it } \\
\text { the pretrial institutions cannot } \\
\text { function maximally because they } \\
\text { are unable to answer the problems } \\
\text { in the pre-adjudication process. }\end{array}$ \\
\hline $\begin{array}{l}\text { 5) Considering, that all actions of the } \\
\text { Investigator in the process of the } \\
\text { Investigation and any action the public } \\
\text { prosecutor in the process of } \\
\text { prosecution that have not been } \\
\text { regulated in Article } 77 \text { Jo in Article } 82 \\
\text { Paragraph (1) Jo Article } 95 \text { paragraph } \\
\text { (1) and (2) of the Criminal Procedure } \\
\text { Code is stipulated as the object of } \\
\text { Pretrial and Institution the law } \\
\text { authorized to test the validity of all the } \\
\text { actions of the Investigator in the } \\
\text { Investigation process and all the } \\
\text { actions of the Prosecutor in the } \\
\text { Prosecution Process is the Pretrial }\end{array}$ & $\begin{array}{l}\text { 5) At the time of the enactment of the } \\
\text { Criminal Procedure Law, the issue } \\
\text { of determining the suspect has not } \\
\text { been a crucial and problematic } \\
\text { issue in the life of Indonesian } \\
\text { society. Forced attempts at that } \\
\text { time were conventionally } \\
\text { interpreted to the extent of arrest, } \\
\text { detention, investigation, and } \\
\text { prosecution, but nowadays forms } \\
\text { of forced attempt have undergone } \\
\text { various developments or } \\
\text { modifications of which one form is } \\
\text { the "investigation of suspects by } \\
\text { investigators" conducted by the }\end{array}$ \\
\hline
\end{tabular}




\begin{tabular}{|c|c|}
\hline Institution & $\begin{array}{l}\text { State in the form of label or status } \\
\text { of a suspect to a person in the } \\
\text { absence of a clear deadline, so that } \\
\text { a person is compelled by the State } \\
\text { to accept the suspect's status } \\
\text { without the availability of an } \\
\text { opportunity for him to undertake a } \\
\text { legal effort to test the legality and } \\
\text { purity of the purpose of the } \\
\text { suspect's determination. }\end{array}$ \\
\hline $\begin{array}{l}\text { 6) Considering, that related to the } \\
\text { application of the Applicant, because } \\
\text { the Suspect's determination is part of a } \\
\text { series of Investigator's actions in the } \\
\text { Investigation Process, the legal entity } \\
\text { authorized to test and assess the } \\
\text { validity of 'Suspect Determination' is } \\
\text { the Pretrial Institution }\end{array}$ & $\begin{array}{l}\text { 6) When the determination of a } \\
\text { suspect is not done ideally and } \\
\text { correctly, where a person has been } \\
\text { determined to be a suspect fight for } \\
\text { their rights with the endeavor of } \\
\text { the law that there is something } \\
\text { wrong in setting a person becomes } \\
\text { a suspect. Therefore, the } \\
\text { determination of the suspect is part } \\
\text { of the investigation process that is } \\
\text { a deprivation of human right, then } \\
\text { it should be the determination of a } \\
\text { suspect by the investigator is an } \\
\text { object that can be requested for } \\
\text { protection through the legal effort } \\
\text { of the Pretrial Institution. It is } \\
\text { solely to protect a person from } \\
\text { arbitrary actions of the investigator } \\
\text { who most likely can occur when a } \\
\text { person is named as a suspect, but } \\
\text { in the process it turns out there is a } \\
\text { mistake then there is no institution } \\
\text { other than the institution of pretrial } \\
\text { that can examine and decide upon } \\
\text { it. However, the protection of the } \\
\text { suspect's right does not mean that } \\
\text { the suspect is innocent and does } \\
\text { not abort the allegation of a } \\
\text { criminal offense, so that still can be } \\
\text { done the investigation in } \\
\text { accordance with the applicable law } \\
\text { rules ideally and correctly. }\end{array}$ \\
\hline $\begin{array}{l}\text { 7) Considering whereas the judge } \\
\text { declares the principle of legality not } \\
\text { applicable to criminal procedure law }\end{array}$ & \\
\hline
\end{tabular}


(Table 1: Consideration Of The Pretrial Decision No:04/Pid.Prap/2015/PN.Jak.Sel and Consideration of the Decision of the judicial review of the Constitutional Court Number 21/PUU-XII/2014)

Based on the two judges' considerations that examine and decide that the Pretrial Institution is authorized to conduct a valid hearing of the suspect. therefore the author tries to examine both of consideration of the decision.

In the consideration of Pretrial Decision No: 04/Pid.Prap/2015/PN.Jak.Sel above, it shows that the Judges use the method of discovery of the law of interpretation of the analogy (argumentum per analogiam), the use of the method of interpretation of the analogy (argumentum per analogiam) to withdraw the authority of the testing whether it is a valid determination of the Suspects to expand the authority of Pretrial. According to the author, the method of the discovery of the law of analogy (argumentum per analogiam) used to examine and adjudicate the Pretrial case is very erroneous and prohibited, since it is necessary to know that the principle of legality applies to both material criminal law and formal criminal law.

The principle of legality as contained in the material criminal law, Moeljatno states that the principle of legality, the Latin term "nullum delictum, nulla poena sine praevia legi poenali" (no an act can be imprisoned, in addition to based on the strength of the provisions of the criminal laws that preceded it), containing 3 (three) terms, namely:

1) No act is prohibited and threatened with crime if it has not been declared in a law beforehand;

2) To determine the existence of a criminal act should not use analogy;

3) The rules of criminal law are not retroactive (Moeljanto, 1987: 25).

Whereas, the principle of legality contained in the code of criminal procedure contained in the provisions of Article 3 which determines, justice is done according to the way stipulated in the law. Thus, the relevance of the provisions of the principles of legality both contained in material and formal criminal law are closely related, so that the apparatus, especially the Investigator in cracking down a criminal case, of course, need to ensure that the violated action is a criminal act and the criminal process is carried out in accordance with the applicable procedures, so that all law enforcement is done fairly and there is legal certainty so that the society is free from the arbitrary, handedness thus basically the importance of legality principle which is aimed as follows:

1) Strengthening legal certainty; 
2) Creating justice and honesty of the defendant;

3) Making effective the deterrent function of criminal sanctions;

4) Prevent abuse of power; and

5) Strengthening the application of rule of law (Jaya, 2008: 14).

In the consideration of the verdict of judicial review of the Constitutional Court of Republic of Indonesia Number 21/PUU-XII/2014, using historical interpretation method (historiche intepretatie). The historical interpretation method (historiche intepretatie) is an interpretation method that want to understand the law in the context of the entire history of the law (Prakoso, 2016: 104). It is very clear that in the considerations contained in the table at number 4 it states "The nature of the existence of pretrial institutions is a form of supervision and mechanism of objection to the law enforcement process that is closely related to the guarantee of the protection of human rights". Then, continued on the next consideration in the table at number 5 states "the enactment of the Criminal Procedure Law, the issue of determining the suspect has not been a crucial and problematic issue in the life of Indonesian society. Forced attempts at that time were conventionally interpreted to the extent of arrest, detention, investigation, and prosecution, but nowadays forms of forced attempt have undergone various developments or modifications of which one form is the "investigation of suspects by investigators" conducted by the State in the form of label or status of a suspect to a person in the absence of a clear deadline, so that a person is compelled by the State to accept the suspect's status without the availability of an opportunity for him to undertake a legal effort to test the legality and purity of the purpose of the suspect's determination."

Therefore, the judge must first analyze the initial purpose of the establishment of the Pretrial Institution which aims to determine whether the pretrial institution can guarantee the protection of human rights or not. Actually, there is no problem with this interpretation method. Because the function of judicial review by the Constitutional Court is indeed to examine whether the law is contradictory to the 1945 Constitution or violates the constitutional rights of citizens or not, but which becomes a problem after the constitutional judges do historical interpretation (historiche intepretatie) try to establish the norm as stated in the consideration of constitutional justices presented in the table on the number 6 which states "because the Suspect's determination is part of a series of Investigator's actions in the Investigation Process, the legal entity authorized to test and assess the validity of 'Suspect Determination' is the Pretrial Institution" and at the end of its decision decided that the object of Pretrial include establishing the lawfulness of the suspect. 
Thus, the Constitutional Court seems to experience a shift in function which is to be a positive legislator. The proposition that stating that the Constitutional Court of the Republic of Indonesia is authorized as a positive legislator is the development of the judicial review of the law against the constitution (constitutional review) within the framework of checks and balances conducted by the judiciary which originally categorized by Kelsen as negative legislation, it is now said by Christopher Wolfer, has become "positive legislation", through the so-called "jugde made law" in the constitution which according to him has now been accepted by the United States (Martitah, Jurnal Masalah-Masalah Hukum, Jilid 41 Number 2, April 2012: 317). And it is, described as an emergency door, an attitude of judicial activism by making the verdict of the positive legislature can be one way to maintain a constitutional democratic system (Martitah, Jurnal Masalah-Masalah Hukum, Jilid 41 Number 2, April 2012: 318).

So, it is not justified considering the space for the Constitutional Court as a negative legislator. The Constitutional Court is not authorized to form the new norm or serve as a "positive legislation", remember a few things namely:

1) In the perspective of the juridical-normative to the provisions of Article 56 and Article 57 of the Constitutional Court Law strictly provide space for the Constitutional Court as a negative legislator.

2) As said by legal experts, Logemann, stated that the judge is not allowed to interpret the law arbitrarily. People should not arbitrarily interpret binding rules, only interpretations which are appropriate to the intent of the legislator that are appropriate interpretations (Ardhiwisastra, 2000: 8-9).

Whereas, in the context of the method of legal discovery with interpretation, the judge should still be based on the formulation contained in the law, the consequence is that the judge in performing the interpretation method shall not be excluded from the formulation of the Article and shall not create a new norm formula in the provisions which have been regulated explicit and limitative concerning the authority of the Pretrial. Based on the above, according to the author, the judge should not move from the framework of the Criminal Procedure formulation. However, in the second perspective the judicial authorities above the judge are permitted and may conduct legal discovery as long as it is laid within the framework of the legality principle by the permissible method. Because if there is coercion in the use of methods such as analogy methods in the realm of criminal law in finding the law both in the realm of material criminal law and formal criminal law can be considered arbitrary and potentially arbitrary and injurious human rights outlined in the principle of legality. 
After discussing the method of interpretation used by the judges of Pretrial in granting the unlawful application of the determination of the suspect in Decision No: 04/Pid.Prap/2015/PN.Jak.Sel or by the Constitutional Court Judges by judicial review on decision Number 21/PUU-XII/2014. Then the author will discuss what the implications of Decision No: 04/Pid.Prap/2015/PN.Jak.Sel and the verdict of judicial review of the Constitutional Court RI Number 21/PUU$\mathrm{XII} / 2014$. As discussed above, the interpretation method used by the judges seems to be incorrect.

In the process of law enforcement, since the existence of Decision No: 04/Pid.Prap/2015/PN.Jak.Sel or by the Panel of Judges of the Constitutional Court through judicial review on Decision Number 21/PUU-XII/2014 which granted and stated that the Pretrial Institution is authorized to examine and adjudicate the validity of the determination of the Suspects by Investigators from 2015 to the of when this still has implications for law enforcement or other problems. With the expansion of the authority of the pretrial through the Decision No: 04/Pid.Prap/2015/PN.Jak.Sel or by the Judges of the Constitutional Court through judicial review on the decision Number 21/PUU-XII/2014, so, automatically the more wide open access to pretrial. Applications submitted to the Pretrial be increased along the expansion of such authority, especially especially about testing the determination of the suspect. It can be seen some cases which is as follows:

\begin{tabular}{|c|c|c|c|c|}
\hline Number & $\begin{array}{l}\text { Name of } \\
\text { Applicant }\end{array}$ & Cases & Decision & $\begin{array}{l}\text { Problems that } \\
\text { arise }\end{array}$ \\
\hline 1. & $\begin{array}{l}\text { Hadi Purnomo } \\
\text { (Former } \\
\text { Chairman Of } \\
\text { The Audit } \\
\text { Board of } \\
\text { Indonesia) }\end{array}$ & $\begin{array}{l}\text { The case of } \\
\text { abuse of } \\
\text { authority in the } \\
\text { receipt of the } \\
\text { taxpayer } \\
\text { objection of } \\
\text { PT Bank } \\
\text { Central Asia } \\
\text { (BCA) Tbk in } \\
\text { 1999. At that } \\
\text { time, Hadi still } \\
\text { served as } \\
\text { Director } \\
\text { General of } \\
\text { Taxes Ministry } \\
\text { of Finance and } \\
\text { allegedly cost } \\
\text { the state Rp }\end{array}$ & $\begin{array}{l}\text { Stating that the } \\
\text { investigation and } \\
\text { seizure of goods } \\
\text { by KPK against } \\
\text { Hadi is not valid } \\
\text { and must be } \\
\text { stopped. The } \\
\text { decision also led } \\
\text { to the } \\
\text { termination of } \\
\text { Hadi's status as } \\
\text { a suspect on } \\
\text { Tuesday, May } \\
\text { 26, 2015. } \\
\text { Case stalled }\end{array}$ & $\begin{array}{l}\text { The pretrial has } \\
\text { exceeded its } \\
\text { authority until } \\
\text { it gets into the } \\
\text { subject matter }\end{array}$ \\
\hline
\end{tabular}




\begin{tabular}{|c|c|c|c|c|}
\hline & & 375 billion. & & \\
\hline 2. & $\begin{array}{l}\text { Taufiqurrahman } \\
\text { (The Regent Of } \\
\text { Nganjuk) }\end{array}$ & $\begin{array}{l}\text { corruption } \\
\text { against the five } \\
\text { development } \\
\text { projects in } \\
\text { Nganjuk in } \\
\text { 2016. The } \\
\text { project } \\
\text { development } \\
\text { was done } \\
\text { Taufiq in 2009. } \\
\text { He was } \\
\text { allegedly } \\
\text { involved in the } \\
\text { procurement, } \\
\text { procurement } \\
\text { and lease of } \\
\text { the project on } \\
\text { five } \\
\text { Kedungingas } \\
\text { bridge } \\
\text { construction } \\
\text { projects, the } \\
\text { project for } \\
\text { rehabilitation } \\
\text { of the channel } \\
\text { Melilir } \\
\text { Nganjuk, Road } \\
\text { improvement } \\
\text { project } \\
\text { Sukomoro to } \\
\text { Kecubung, the } \\
\text { project for } \\
\text { rehabilitation } \\
\text { of channel } \\
\text { Gangga } \\
\text { Malang and } \\
\text { projects } \\
\text { periodic } \\
\text { maintenance of } \\
\text { the } \\
\text { Ngangkrek to } \\
\text { Mblora }\end{array}$ & $\begin{array}{l}\text { The filing of pre- } \\
\text { trial is finally } \\
\text { granted by the } \\
\text { Judge I Wayan } \\
\text { Karya, with a } \\
\text { consideration of } \\
\text { the Letter of } \\
\text { Joint Decree } \\
\text { (SKB) } \\
\text { This pretrial } \\
\text { granting makes } \\
\text { the KPK } \\
\text { dissatisfied. The } \\
\text { KPK then filed a } \\
\text { Taufiq case file } \\
\text { and a pretrial } \\
\text { decision to the } \\
\text { Attorney } \\
\text { General's Office } \\
\text { (AGO). Director } \\
\text { of Investigation } \\
\text { of Deputy } \\
\text { Attorney General } \\
\text { for Special } \\
\text { Crimes } \\
\text { (Jampidsus) } \\
\text { Warih Sadono } \\
\text { said the AGO is } \\
\text { still considering } \\
\text { the next } \\
\text { decision. } \\
\text { Possibilities such } \\
\text { as the issuance } \\
\text { of a new } \\
\text { investigation } \\
\text { warrant the } \\
\text { commence an } \\
\text { investigation will } \\
\text { still } \\
\text { considered by } \\
\text { the AGO. Until } \\
\text { now, } \\
\text { investigation of }\end{array}$ & $\begin{array}{l}\text { Case becomes } \\
\text { unfinished } \\
\text { (abandoned) }\end{array}$ \\
\hline
\end{tabular}




\begin{tabular}{|c|c|c|c|c|}
\hline & & & $\begin{array}{l}\text { this } \\
\text { continues }\end{array}$ & \\
\hline 3. & $\begin{array}{l}\text { Ilham Arief } \\
\text { Sirajuddin } \\
\text { (Former Mayor } \\
\text { Of Makassar) }\end{array}$ & $\begin{array}{l}\text { Corruption of } \\
\text { the } \\
\text { Management } \\
\text { of the Regional } \\
\text { Water } \\
\text { Company } \\
\text { (PDAM) } \\
\text { Makassar City } \\
2006-2012\end{array}$ & $\begin{array}{l}\text { 1) First pre-trial } \\
\text { judgment. } \\
\text { Ilham } \\
\text { produced } \\
\text { three } \\
\text { important } \\
\text { points, namely } \\
\text { the } \\
\text { determination } \\
\text { of Ilham as a } \\
\text { suspect } \\
\text { considered } \\
\text { invalid, then } \\
\text { the seizure, } \\
\text { the search and } \\
\text { the blocking } \\
\text { of accounts } \\
\text { belongs to } \\
\text { Ilham that is } \\
\text { not valid as } \\
\text { well as the } \\
\text { judge's the } \\
\text { instructions to } \\
\text { the KPK to } \\
\text { restore the } \\
\text { civil and } \\
\text { political rights } \\
\text { of Ilham } \\
\text { 2) The second } \\
\text { Pretrial } \\
\text { Decision, } \\
\text { Judge Amat } \\
\text { considered } \\
\text { that two } \\
\text { evidences by } \\
\text { the KPK, } \\
\text { which is the } \\
\text { Report of } \\
\text { Inquiry Result } \\
\text { of } \\
\text { Supreme } \\
\text { Audit Board } \\
\text { has }\end{array}$ & $\begin{array}{l}\text { The law } \\
\text { enforcement } \\
\text { process takes a } \\
\text { long time }\end{array}$ \\
\hline
\end{tabular}




\begin{tabular}{|c|c|c|c|c|}
\hline & & & $\begin{array}{ll}\text { strong } & \text { to } \\
\text { establish } & \\
\text { Ilham as a } \\
\text { suspect. }\end{array}$ & \\
\hline 4. & $\begin{array}{l}\text { Marthen Dira } \\
\text { Tome (Former } \\
\text { Regent of Sabu } \\
\text { Raijua NTT) }\end{array}$ & 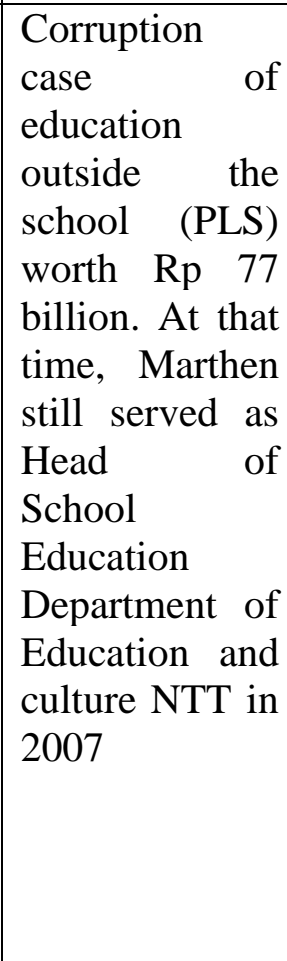 & $\begin{array}{l}\text { 1) Pretrial } \\
\text { Decision I, its } \\
\text { pre-trial } \\
\text { lawsuit was } \\
\text { granted on } \\
\text { May 18, } 2016 \\
\text { 2) Reapply the } \\
\text { pre-trial } \\
\text { lawsuit for the } \\
\text { second time. } \\
\text { However, it } \\
\text { has not yet } \\
\text { completed its } \\
\text { pre-trial } \\
\text { lawsuit, KPK } \\
\text { officials } \\
\text { arrested } \\
\text { Marthen at a } \\
\text { restaurant in } \\
\text { NTT }\end{array}$ & $\begin{array}{l}\text { 1) The } \\
\text { Investigator } \\
\text { does not } \\
\text { respect the } \\
\text { Judicial } \\
\text { Process by } \\
\text { awaiting } \\
\text { Pretrial } \\
\text { Decision a } \\
\text { second time. } \\
\text { 2) The } \\
\text { settlement of } \\
\text { the case } \\
\text { takes a long } \\
\text { time }\end{array}$ \\
\hline 5. & Dahlan Iskan & $\begin{array}{l}\text { 1) Cases of } \\
\text { alleged } \\
\text { corruption } \\
\text { assets of } \\
\text { Regionally- } \\
\text { Owned } \\
\text { Enterprises } \\
\text { of East Java } \\
\text { 2) Cases of } \\
\text { alleged } \\
\text { corruption } \\
\text { procurement } \\
\text { of 16 units } \\
\text { of the } \\
\text { electric car } \\
\text { 3) Cases of } \\
\text { alleged } \\
\text { corruption } \\
\text { in the } \\
\text { construction } \\
\text { of } 21\end{array}$ & $\begin{array}{l}\text { 1) Pretrial } \\
\text { Decision on } \\
\text { Alleged } \\
\text { corruption in } \\
\text { the } \\
\text { Construction } \\
\text { of the } 21 \\
\text { Substations. } \\
\text { Stated the } \\
\text { Investigation } \\
\text { is not } \\
\text { considered } \\
\text { compatible } \\
\text { with the } \\
\text { legislation, } \\
\text { then the } \\
\text { Determinatio } \\
\mathrm{n} \text { of the } \\
\text { Suspect is not } \\
\text { valid } \\
\text { 2) Pretrial }\end{array}$ & $\begin{array}{l}\text { 1) The } \\
\text { settlement of } \\
\text { the case } \\
\text { takes a long } \\
\text { time } \\
\text { 2) Potential } \\
\text { disparity of } \\
\text { the judge's } \\
\text { decision }\end{array}$ \\
\hline
\end{tabular}




\begin{tabular}{|c|c|c|c|c|}
\hline & & $\begin{array}{l}\text { substations } \\
\text { in Java, Bali } \\
\text { and Nusa } \\
\text { Tenggara in } \\
2011-2013\end{array}$ & $\begin{array}{l}\text { decision for } \\
\text { alleged } \\
\text { corruption } \\
\text { cases of } \\
\text { Regionally- } \\
\text { Owned } \\
\text { Enterprises } \\
\text { assets is to } \\
\text { reject the pre- } \\
\text { trial } \\
\text { application } \\
\text { filed by } \\
\text { Dahlan Iskan } \\
\text { as the suspect } \\
\text { case } \\
\text { 3) Pretrial } \\
\text { decision in } \\
\text { cases of } \\
\text { alleged } \\
\text { corruption } \\
\text { the electric } \\
\text { car is rejected } \\
\text { so that the } \\
\text { determination } \\
\text { of Suspect } \\
\text { valid }\end{array}$ & \\
\hline 6. & La Nyalla & $\begin{array}{l}\text { The alleged } \\
\text { corruption of } \\
\text { the grant of } \\
\text { Indonesia } \\
\text { Chamber of } \\
\text { Commerce and } \\
\text { Industry of } \\
\text { East Java in } \\
2012\end{array}$ & $\begin{array}{l}\text { It has been } 3 \\
\text { (three) times } \\
\text { filed a Pretrial } \\
\text { Appeal and all } \\
\text { pretrial decisions } \\
\text { stating that the } \\
\text { determination of } \\
\text { the Suspect is } \\
\text { illegal }\end{array}$ & $\begin{array}{l}\text { The process is } \\
\text { still running. }\end{array}$ \\
\hline
\end{tabular}

(Table 2: Cases of Pretrial Filing, Setyani,

https://www.rappler.com/indonesia/berita/183114-para-pemenang-gugatanpraperadilan-melawan-kpk, accessed on January 25, 2018; Rahardian, https://www.cnnindonesia.com/nasional/20150804130722-12-69965/gugatandahlan-iskan-dikabulkan-status-tersangka-gugur, accessed on January 25, 2018; Wahyudiyanta, https://news.detik.com/berita-jawa-timur/d-3215971/untuk-ketigakalinya-gugatan-praperadilan-la-nyalla-dikabulkan-pengadilan, accessed on January 25, 2018) 
Nevertheless there is a claim that the judicial review of the Constitutional Court of the Republic of Indonesia Number 21/PUU-XII/2014 provides protection against a person who is experiencing a wrong legal process at the time as a suspect. In the provisions of Article 8 of the Law Number 39 of 1999 on Human Rights it is stipulated that "Protection, promotion, enforcement, and fulfillment of human rights are primarily the responsibility of the government". At a glance it can be corrected but we need to study also in terms of the principles of the criminal justice system in Indonesia which is contained in the Criminal Procedure Code, it will be a test of whether the verdict of the judicial review of the Constitutional Court of the Republic of Indonesia really provides the protection of human rights against a person who went through the wrong legal process?

Based on the table above, it can be said that since the existence of the extension of the authority of the Pretrial is to examine and decide whether or not the suspect suffers a lot of various problems, especially in the field of law enforcement. As it is well known that Pretrial just checks things that only examine the things that are formal administrative procedural or in other words administrative review, not the substance of the case (principal case), whereas according to Indriyanto Seno Adji said the judge of Pretrial just has limited authority on examine judge and it is not against the authority of testing all forced efforts conducted by the Investigator (Adji,2015: 5). Thus, it certainly does not recognize Ne Bus In Idem. This is what causes the process of settling the case takes a long time and of course it is also contradictory to the principles contained in the criminal justice system which include:

1) The principle of fast, simple and low budget justice

2) The principle of litis finiri oportet.

The principle of fast, simple and low cost justice and the principle of litis finiri oportet is closely related, as it is known based on the data table of the application for the pre-trial application in examining the validity of the suspect's determination of course the problem that arises is the duration of the process of law enforcement and settlement of course this is very contrary because every decision a pretrial course will be a legal effort, either by the applicant by reapplying for the pretrial appeal to re-determination of its Suspect status, while on the legal remedy filed by the law enforcement apparatus that is by issuing a new investigation warrant again. This is because in the legal instrument made by the Supreme Court of the Republic of Indonesia, Supreme Court Regulation No 4 of 2016 on the Prohibition of Review of Pretrial Decision in Article 2 paragraph (3) states "Pretrial Decision which grants the petition about the invalid determination of the suspect does not abort the authority of the Investigator to determine 
concerned as a suspect again after fulfilling at least two valid new legal instruments, unlike the previous evidence relating to the matter of the case ". This, of course, greatly disrupts the law enforcement process that causes the length of the settlement process and could potentially even end up in the non-completion of a case settlement and this has an impact on the swelling cost of law enforcement, because every process of law enforcement certainly costs a lot. Thus the extension of Pretrial authority based on the judicial review decision violates the human rights of the Suspects themselves because the case becomes the long-term settlement so that it has the potential to not provide certainty of its legal status and certainly this could potentially also become selective logging conducted individual subsystems of criminal justice in Indonesia. It is not excessive, if Indriyanto Omar Seno Adji states "law enforcers, not only the KPK, also the Police and the Attorney should prepare Pretrial currents with a new face with these two sides, namely as a base of protection rights and the provision of the rights of the Suspects, but on the side others may also pose a substantial risk of eradicating corruption crimes " (Adji,2015: 5).

The extension of the authority of the Pretrial Court also caused other problems namely the use of procedural law in the Pretrial process which used the Civil Procedure Code. This is based only on practices that have existed because there is no clear regulatory construction on them. Pretrial is interpreted as a testing mechanism related to formal problems. Procedural, and administrative in a criminal proceeding process. Therefore, civil procedure law that emphasizes formal truth seeking is used as a pre-trial procedural law. So the consequence is that the process of Pretrial examination is only to seek formal truth. In searching for formal truth, just enough judges to prove the preponderance of the evidence (Mertokusumo, 2002: 141). And if with only focus on proving the preponderance of the evidence alone, then proven level will be weak (Fuady, 2006: 46). Because only the formal Truth is sought in the context of civil procedure law that actually makes pretrial also confined in it. Law enforcers and justiabelen parties in completing the legal process need to understand how to solve by observing the principle of Heuristics which is an important process in criminal law enforcement. This process is related to two issues, namely structuring facts and structuring rules (Sidharta, 2016: 9). The criminal law enforcement process cannot be separated from the heuristic because it is a process to restructure the crime from investigation to a permanent law enforcement (Inkracht van gewijsde / res judicata) in searching, finding and at least approaching material truth. Material truth certainly cannot be separated from the process of proving and reconstructing the facts or events which in the criminal justice process the position of law 
enforcers should lead to a final decision (Gumbira, Jurnal Hukum dan Pembangunan, Number 1, 2016: 113).

Thus, it can be said that the extension of authority given to pretrial through Constitutional Court Decision Number 21/PUU-XII/2014 which is not followed by strengthening the construction of pretrial arrangement precisely causing chaos in its implementation and potentially hampering law enforcement and can harm the constitutional rights of the Suspects or the Justiabelen itself because the case takes a long time of completion without the certainty of the settlement. Thus, it can be said that the model of submission of judicial review testing on two different State institutions is actually vulnerable to give birth to legal issues, even potentially damaging the pillars of law (Simamora, Jurnal Mimbar Hukum, Number 3, Oktober 2013: 399), if done without seeing the harmonization of legal instrument relationships with each other because the law is a unity interrelated systems.

\section{E. CLOSING}

Based on the above description and discussion, the authors give the following conclusions:

That the interpretation method used in Pretrial Decision No: 04/Pid.Prap/2015/PN.Jak.Sel is the method of discovery of analogy interpretation law (argumentum per analogiam). The method of the discovery of the analogy (argumentum per analogiam) law used to examine and adjudicate the Pretrial case is false and prohibited, since it is necessary to recognize that the principle of legality applies to both material criminal law and formal criminal law. While the interpretation method used by the Constitutional Court of the Republic of Indonesia in the judicial review verdict Number 21/PUU-XII/2014 that is using the method of historical interpretation (historiche intepretatie) which became the problem that the Constitutional Court has exceeded the function of its previously negative legislator becomes a positive legislator so as to form or add a new norm, of course it is not justified because of its normative juridical provisions as stipulated in Article 56 and Article 57 of the Law, the Constitutional Court of the Republic of Indonesia strictly provides space for the Constitutional Court as a negative legislator, so that it implies as being 2 (two) sides of the currency, in one side has the potential to be an obstacle to the law enforcement process and even infringes, harms the Suspects' own human rights because the process of settling the case takes a long time and floats the legal status of the Suspects. On the other hand can also be one of the means of check and balance against the actions forced the Investigators to a Suspect as a form of protection rights. 


\section{BIBLIOGRAPHY}

\section{Books:}

Abintoro Prakoso, 2016, Penemuan Hukum, Sistem, Metode, Aliran Dan Prosedur Dalam Menemukan Hukum (Rechtsvinding, System, Methods, Sect, and Procedur in The Finding of Law), Laksabang: Yogyakarta.

Achmad Ali, 2015, Menguak Tabir Hukum ,Edisi Kedua (Uncovering The Veil of Law, Second Edition ), Jakarta: Kencana Prenada Grup.

Indriyanto Seno Adji, 2015, Praperadilan \& KUHAP,catatan mendatang (PreTrial and KUHAP, Future Notes), Diadit Media: Jakarta..

MoeljatNumber, 1987, Asas Asas Hukum Pidana (Criminal Law Priciples), Bina Aksara: Jakarta.

Munir Fuady, 2006, Teori Hukum Pembuktian (Theory on Law of Evidence), Citra Aditya Bakti: Bandung.

Nyoman Sarikat Putra Jaya, 2008, Beberapa Pemikiran Ke Arah Pengembangan Hukum PIdana (Some Thoughts Towards The Development of Criminal Law), Citra Adiya Bakti: Bandung.

Sidharta, 2016, Heurestika dan Hermeneutika: Penalaran Hukum Pidana. Artikel pada Demi Keadilan Antologi HUkum Pidana dan Sistem Peradilan Pidana (Heurestics and Hermeneutics: Criminal Law Reasoning. Articles on "For" the Justice of Criminal Law and The Criminal Justice System): 6 Dasawarsa Harkristuti Harkrisnowo, Pustaka Kemang: Jakarta.

Sri Soemantri, 1990, Bunga Rampai Hukum Tata Negara Indonesia (Potpourri of The Constitutional Law), Alumni: Bandung.

Sudikno Mertokusumo, 2002, Hukum Acara Perdata Indonesia (Indonesia Privat Procedur Law), Liberty: Yogyakarta.

Soerjono Soekanto dan Sri Mamuji, 2007, Penelitian Hukum Normatif Suatu Tinjauan Singkat (Normative Legal Research, a Simple Review), Rajawali Press: Jakarta.

Yudha Bhakti Ardhiwisastra, 2000, Penafsiran dan Konstruksi Hukum (Interpretation and Legal Construction), Alumni: Bandung.

\section{Journals}

Janpatar Simamora. "Analisa Yuridis Terhadap Model Kewenangan Yudicial Review di Indonesia”. Yogyakarta Jurnal Mimbar Hukum FH UGM Vol 25 No 3 Oktober 2013. 
Martitah. "Progresivitas Hakim Konstitusi Dalam Membuat Putusan (Analisis Terhadap Keberadaan Putusan Mahkamah Konstitusi yang bersifat Positive Legislature)”. Jurnal Masalah-Masalah Hukum Jilid 41 No2, April 2012. FH UNDIP. Semarang.

Muchamad Ali Safa'at, "Kekuatan Mengikat Dan Pelaksanaan Putusan MK”, Makalah, Malang Universitas Brawijaya

Seno Wibowo Gumbira. "Problematika Peninjauan Kembali Dalam Sistem Peradilan Pidana Pasca Putusan Mahkamah Konstitusi Dan Pasca SEMA RI Number 7 Tahun 2014 (Suatu Analisa Yuridis Dan Asas-Asas Dalam Hukum Peradilan Pidana)”. Depok. Jurnal Hukum dan Pembangunan Vol 46 No 1 Tahun 2016 FH UI

\section{Internet:}

http://www.mahkamahkonstitusi.go.id/index.php?page=web.Berita\&id=10796\#. WIXAeqiWbs0 downloaded on January 10, 2018

Syukri Asy'ari, Meyrinda Rahmawaty Hilipito, Mohammad Mahrus Ali. 2012. Model dan Implementasi Putusan Mahkamah Konstitusi Dalam Pengujian Undang-Undang (Studi Putusan tahun 2003-2012). Jakarta: Pusat Penelitian dan Pengkajian Perkara Pengelolaan Teknologi Informasi Dan Komunikasi Kepaniteraan dan Sekertariat Jenderal Mahkamah Konstitusi RI

https://www.rappler.com/indonesia/berita/183114-para-pemenang-gugatanpraperadilan-melawan-kpk each one accessed on January 25, 2018

https://www.cnnindonesia.com/nasional/20150804130722-12-69965/gugatandahlan-iskan-dikabulkan-status-tersangka-gugur each one accessed on January 25, 2018

https://news.detik.com/berita-jawa-timur/d-3215971/untuk-ketiga-kalinyagugatan-praperadilan-la-nyalla-dikabulkan-pengadilan each one accessed on January 25, 2018

Muchamad Ali Safa'at, Penafsiran Konstitusi, downloaded from http://safaat.lecture.ub.ac.id/2011/11/penafsiran-konstitusi/, accessed on January 10, 2018 